Article

\title{
Analysis of Boswellic Acid Contents and Related Pharmacological Activities of Frankincense-Based Remedies That Modulate Inflammation
}

\author{
Friedemann Börner ${ }^{1,+}$, Markus Werner ${ }^{1,+}$, Johannes Ertelt ${ }^{2}$, Jürgen Meins ${ }^{3}$, Mona Abdel-Tawab ${ }^{3,4}$ and \\ Oliver Werz ${ }^{1, * \text { (D) }}$
}

1 Department of Pharmaceutical/Medicinal Chemistry, Institute of Pharmacy, Friedrich-Schiller-University, Philosophenweg 14, 07743 Jena, Germany; friedemann.boerner@uni-jena.de (F.B.); werner.markus@uni-jena.de (M.W.)

2 Heidelberg-Apotheke/AureliaSan GmbH, Steinhofener Str. 12-16, 72406 Bisingen, Germany; johannes@ertelt.de

3 Central Laboratory of German Pharmacists, Carl-Mannich-Str. 20, 65760 Eschborn, Germany; j.meins@zentrallabor.com (J.M.); tawab@em.uni-frankfurt.de (M.A.-T.)

4 Institute of Pharmaceutical Chemistry, Johann Wolfgang Goethe University, Max-von-Laue-Straße 9, 60438 Frankfurt am Main, Germany

* Correspondence: oliver.werz@uni-jena.de; Tel.: +49-3641-9498-01

+ Authors contributed equally.

check for updates

Citation: Börner, F.; Werner, M.; Ertelt, J.; Meins, J.; Abdel-Tawab, M.; Werz, O. Analysis of Boswellic Acid

Contents and Related Pharmacological Activities of Frankincense-Based Remedies That Modulate Inflammation. Pharmaceuticals 2021, 14, 660. https://doi.org/10.3390/ ph14070660

Academic Editor: Daniela De Vita

Received: 9 June 2021

Accepted: 7 July 2021

Published: 10 July 2021

Publisher's Note: MDPI stays neutral with regard to jurisdictional claims in published maps and institutional affiliations.

Copyright: (c) 2021 by the authors. Licensee MDPI, Basel, Switzerland. This article is an open access article distributed under the terms and conditions of the Creative Commons Attribution (CC BY) license (https:/ / creativecommons.org/licenses/by/ $4.0 /)$.
Abstract: Extracts of frankincense, the gum resin of Boswellia species, have been extensively used in traditional folk medicine since ancient times and are still of great interest as promising antiinflammatory remedies in Western countries. Despite their common therapeutic use and the intensive pharmacological research including studies on active ingredients, modes of action, bioavailability, pharmacokinetics, and clinical efficacy, frankincense preparations are available as nutraceuticals but have not yet approved as a drug on the market. A major issue of commercially available frankincense nutraceuticals is the striking differences in their composition and quality, especially related to the content of boswellic acids (BAs) as active ingredients, mainly due to the use of material from divergent Boswellia species but also because of different work-up and extraction procedures. Here, we assessed three frequently used frankincense-based preparations for their BA content and the interference with prominent pro-inflammatory actions and targets that have been proposed, that is, 5-lipoxygenase and leukotriene formation in human neutrophils, microsomal prostaglandin $E_{2}$ synthase- 1 , and inflammatory cytokine secretion in human blood monocytes. Our data reveal striking differences in the pharmacological efficiencies of these preparations in inflammation-related bioassays which obviously correlate with the amounts of BAs they contain. In summary, high-quality frankincense extracts display powerful anti-inflammatory effectiveness against multiple targets which can be traced back to BAs as bioactive ingredients.

Keywords: frankincense; boswellic acids; 5-lipoxygenase; microsomal prostaglandin $\mathrm{E}_{2}$ synthase-1; inflammation

\section{Introduction}

Frankincense, the gum resin from various Boswellia species, is an ancient remedy used for centuries in Asian and African folk medicine, especially in traditional Ayurvedic medicine in India [1-3]. Preparations from frankincense have been externally applied for the treatment of wounds and skin disorders but also internal use has long been commonly practiced in order to cure a variety of inflammatory and infectious diseases [2]. In Western societies and modern folk medicine, frankincense preparations are among the most popular natural remedies for treatment of inflammatory disorders such as rheumatoid arthritis and osteoarthritis, inflammatory bowel diseases, multiple sclerosis, respiratory diseases 
including asthma, and cancers [4-7]. The interest in frankincense-based medicine is still rising due to continuous reports about beneficial effects in numerous (pilot) clinical trials where efficacy and safety have been demonstrated $[4,7]$. Moreover, frankincense typically contains boswellic acids (BAs) that are unique pentacyclic triterpene acids with multiple pharmacological actions (e.g., inhibition of 5-lipoxygenase (5-LOX), I-kB kinases, cathepsin G, LL-37, or microsomal prostaglandin $E_{2}$ synthase (mPGES)-1) seemingly accounting for the anti-inflammatory and antitumoral properties $[4,6,8]$.

Given the expanding market of dietary botanicals not undergoing any pre-marketing authorization for quality and efficacy, concerns regarding quality issues are justified. Several studies revealed, aside from economic adulteration, significant differences in the amount of active ingredients compared to the label. In addition, misleading labels are common, although prohibited by regulation [9-11]. In consideration of the increasing popularity of frankincense-based remedies and the justified quality problems associated with dietary botanicals, a preliminary survey was recently conducted on the quality of frankincense-containing dietary botanicals [12]. Among other deficiencies, $41 \%$ of the 17 tested top-selling products from the USA and Europe did not comply with label declaration. This was verified by another study, demonstrating that the total contents $(w / w)$ of the six BAs and two lupeolic acids varied between 0.4 to $35.7 \%$ in 17 tested frankincense nutraceuticals purchased from USA, Europe, and India [13]. In fact, this study demonstrated a clear correlation between the BA contents and the tested inhibitory effect on the pro-inflammatory cytokines tumor necrosis factor (TNF)- $\alpha$, interleukin (IL)- $1 \beta$, IL-6, and IL-8, and the exerted cytotoxic effect against triple-negative breast cancer cell lines could be further proven in vitro.

In an attempt to combat the jumble of qualitatively different frankincense products in the botanical dietary market, capsules containing Boswellia serrata extracts of the highest pharmaceutical quality complying with the requirements of the European Pharmacopoeia monograph for "Indian Frankincense" (monograph 10.0/2310) are now available for therapeutic use. However, the specifications for Indian frankincense to be classified as an extract of pharmaceutical quality are very restricted, not exceeding a demand of at least $1 \%$ content of the lead compounds 11-keto- $\beta$-BA (KBA) and 3-acetyl-11-keto- $\beta$-BA (AKBA). Meanwhile, a plethora of scientific studies in the last years revealed that other BAs (e.g., $\beta B A$ and $A \beta B A$ ) also display anti-inflammatory effects with even higher potencies than KBA and AKBA for relevant inflammatory molecular targets such as LL-37, cathepsin G, or mPGES-1 [4].

The present study aimed at analyzing the comparability of frequently used commercial Boswellia serrata-based remedies for pharmaceutical quality, employing (i) "Sallaki ${ }^{\circledR}$ Tablets", an Indian authorized medicinal product, (ii) "H15 Ayurmedica ${ }^{\circledR}$ ", representing a renowned German frankincense-containing dietary botanical, and (iii) "BOSWELLIASAN ${ }^{\circledR}$ " that are Indian frankincense capsules. For this purpose, the content of the six major BAs (KBA, AKBA, $\beta B A, A \beta B A, \alpha-B A$, and $A \alpha B A$ ) were determined in each preparation, and the efficiency to interfere with inflammation-relevant molecular targets (i.e., 5-LOX, mPGES-1, and cytokines) was evaluated in cell-free and/or cell-based models using appropriate cell types.

\section{Results}

\subsection{Analytical Assessment of Boswellic Acids in Frankincense-Based Remedies}

The quantification of the six characteristic BAs revealed two different fingerprint profiles (Figure 1). Thus, the analytical fingerprints of "Sallaki ${ }^{\circledR}$ Tablets" and "BOSWELLIASAN ${ }^{\circledR}$ " were easily distinguishable from that of "H15 Ayurmedica ${ }^{\circledR}$. . Whereas both "Sallaki ${ }^{\circledR}$ Tablets" and "BOSWELLIASAN ${ }^{\circledR}$ " contained the six characteristic BAs in plausible amounts, "H15 Ayurmedica ${ }^{\circledR}$ " contained only traces of the determined BAs not exceeding $1.92 \mathrm{mg} /$ capsule. Moreover, the amounts of the non-acetylated non-ketylated BAs $(\alpha B A, \beta B A)$ were found to be higher than the respective acetylated non-ketylated BAs (A $\alpha$ BA, $A \beta B A)$ in "Sallaki ${ }^{\circledR}$ Tablets" and "BOSWELLIASAN ${ }^{\circledR "}$ compared to "H15 Ayurmedica ${ }^{\circledR ”}$ as can be seen in Table 1. 


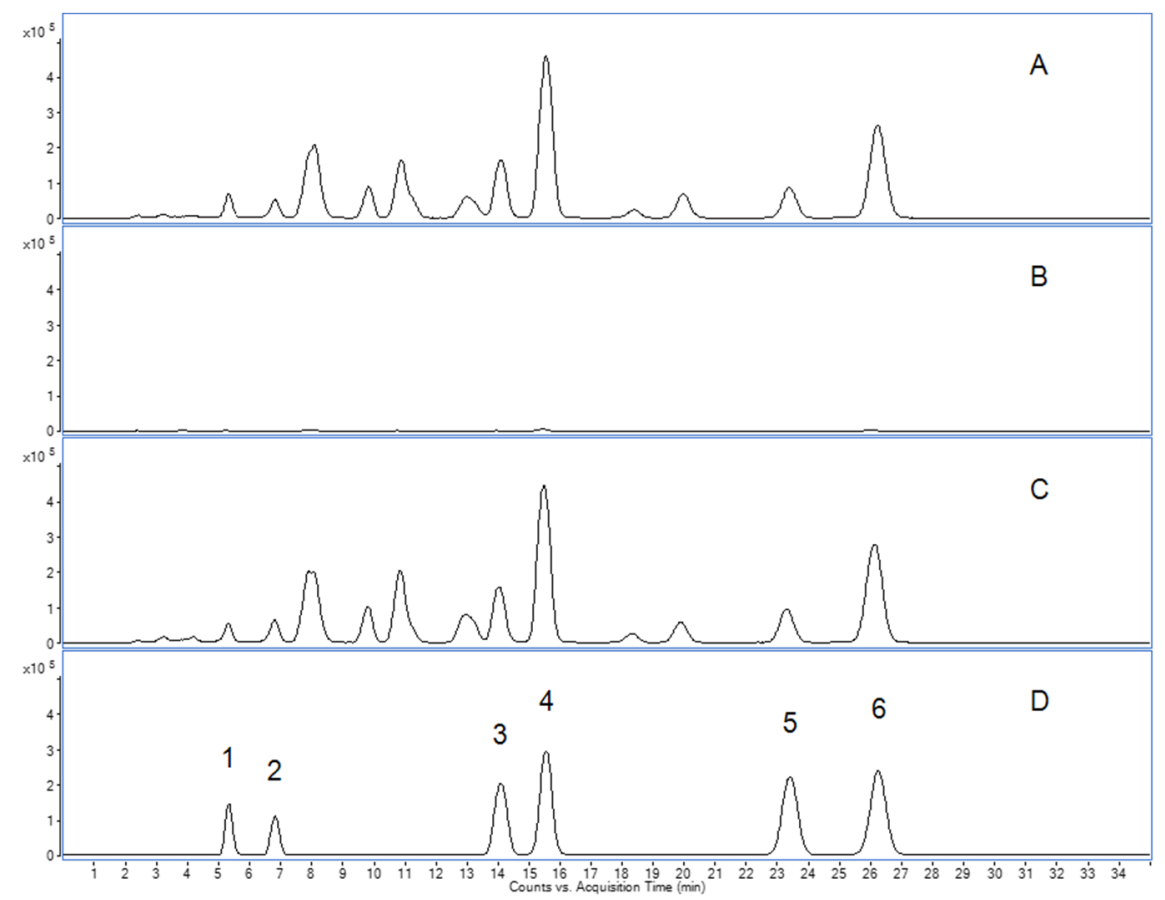

Figure 1. Representative TIC-chromatograms of frankincense-based products. (A) "Sallaki ${ }^{\circledR}$ Tablets". (B) "H15 Ayurmedica ${ }^{\circledR}$ ". (C) "BOSWELLIASAN ${ }^{\circledR}$ ". (D) Standard solution with $1.2 \mu \mathrm{g} / \mathrm{mL}$ of each BA. $1=\mathrm{KBA}, 2=\mathrm{AKBA}, 3=\alpha$-BA, $4=\beta$-BA, $5=$ Acetyl- $\alpha$-BA, $6=$ Acetyl- $\beta$-BA. Experimental conditions and parameter can be found in the Method section.

Table 1. Content of the six characteristic boswellic acids in frankincense products quantified by LC-MS/MS. The amounts of declared extract and of BAs are given in $\mathrm{mg} /$ tablet or capsule, each.

\begin{tabular}{ccccccccccc}
\hline Name & Batch & Dosage Form & $\begin{array}{c}\text { Declared } \\
\text { Extract } \\
\text { Content }\end{array}$ & KBA & AKBA & $\boldsymbol{\alpha}$ BA & $\beta-B$ A & A $\boldsymbol{\alpha B A}$ & A $\beta$ BA & $\sum$ of BA \\
\hline Sallaki $^{\circledR}$ tablets & AB18024 & $\begin{array}{c}\text { tablets } \\
\text { oily capsules } \\
\text { hard }\end{array}$ & 400 & 9.34 & 7.88 & 20.73 & 52.65 & 7.77 & 25.72 & 124.07 \\
H15 Ayurmedica $^{\circledR}$ & 171 & 400 & 0.30 & 0.31 & 0.40 & 0.27 & 0.33 & 0.32 & 1.92 \\
BOSWELLIASAN $^{\circledR}$ & HBPC11 & $\begin{array}{c}\text { gelatin } \\
\text { capsule }\end{array}$ & 300 & 5.12 & 7.51 & 13.58 & 36.40 & 6.45 & 21.16 & 90.21 \\
\hline
\end{tabular}

\subsection{Inhibition of 5-Lipoxygenase and Microsomal Prostaglandin $E_{2}$ Synthase-1 by} Frankincense-Based Remedies

In order to study the effectiveness of the three frankincense-based remedies for inhibition of 5-LOX and mPGES-1, we performed well-documented cell-free activity assays of the respective human enzymes. Purified human recombinant 5-LOX was pre-incubated with the test items for $15 \mathrm{~min}$ at $4{ }^{\circ} \mathrm{C}$ and the enzymatic conversion of exogenously added AA $(20 \mu \mathrm{M})$ the products tr-LTB 4 , etr-LTB 4 , and 5-H(P)ETE were assessed by RP-HPLC; the 5-LOX inhibitor zileuton was used as reference drug. As shown in Figure 2a, "Sallaki ${ }^{\circledR}$ Tablets" and "BOSWELLIASAN ${ }^{\circledR}$ " concentration-dependently inhibited 5-LOX product formation with $\mathrm{IC}_{50}$ values of 17 and $19 \mu \mathrm{g} / \mathrm{mL}$, respectively. In contrast, "H15 Ayurmedica ${ }^{\circledR}$ " was hardly active and even at the highest concentration tested $(50 \mu \mathrm{g} / \mathrm{mL})$ suppressed 5-LO activity by only $\sim 30 \%$ (Figure 2). Zileuton at $3 \mu \mathrm{M}$ inhibited 5-LOX activity by 50\% (Figure 2 b), as expected [14]. 
(a)

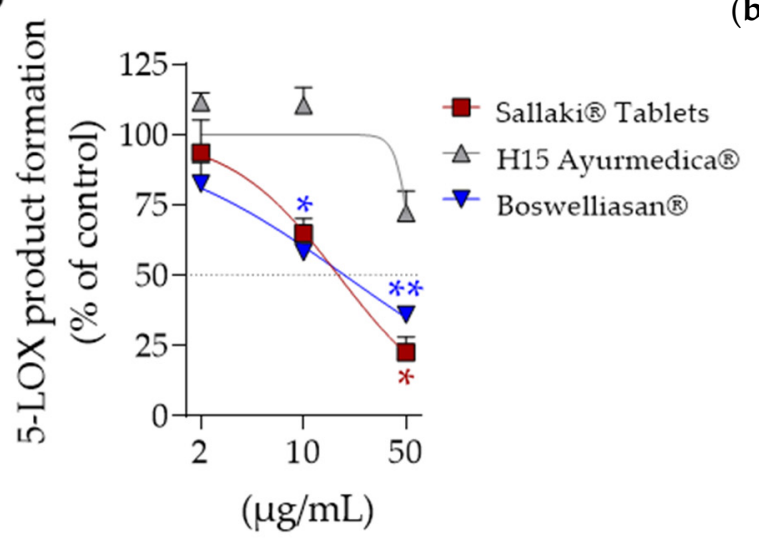

(b)

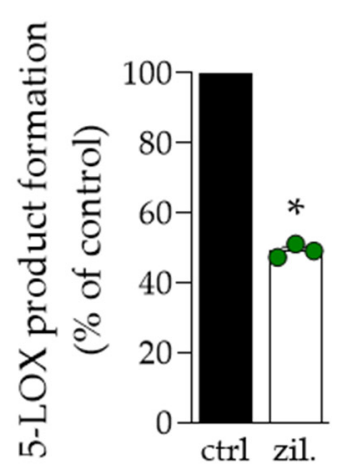

Figure 2. Effects of frankincense-based remedies on 5-LOX activity. (a) Purified human recombinant 5-LOX was incubated with 2,10 , or $50 \mu \mathrm{g} / \mathrm{mL}$ of frankincense-based remedies or vehicle $(0.1 \% \mathrm{EtOH})$ for 15 min at $4{ }^{\circ} \mathrm{C}$ and stimulated with $20 \mu \mathrm{M}$ AA and $2 \mathrm{mM} \mathrm{CaCl}_{2}$ at $37^{\circ} \mathrm{C}$. Formed 5-LOX products (sum of tr-LTB 4 , etr-LTB 4 , 5-H(P)ETE) were purified by SPE and analyzed using RP-HPLC. Data, expressed as percentage of control, are given as mean \pm S.E.M., $\mathrm{n}=3$; repeated measures ANOVA + Dunnett post hoc test with raw data; ${ }^{*} p<0.05$; ${ }^{* *} p<0.01$; vs. vehicle. (b) Zileuton $(3 \mu \mathrm{M})$ was used as positive control under the same experimental conditions as above. Paired $t$-test; ${ }^{*} p<0.05$ vs. vehicle.

The activity of mPGES- 1 was assayed in microsomes of IL- $1 \beta$-activated human A549 cells that received $20 \mu \mathrm{M} \mathrm{PGH} 2$ as substrate for enzymatic conversion to $\mathrm{PGE}_{2}$. Pretreatment with "BOSWELLIASAN ${ }^{\circledR}$ " caused most potent suppression of mPGES-1 activity $\left(\mathrm{IC}_{50}=6.9 \mu \mathrm{g} / \mathrm{mL}\right)$ followed by "Sallaki ${ }^{\circledR}$ Tablets" $\left(\mathrm{IC}_{50}=14 \mu \mathrm{g} / \mathrm{mL}\right)$ while "H15 Ayurmedica ${ }^{\circledR \prime \prime}$ was again less active ( $\mathrm{IC}_{50}$ approx. $50 \mu \mathrm{g} / \mathrm{mL}$ ) (Figure 3a). MK-886, used as reference inhibitor, suppressed mPGES-1 activity (Figure 3b), as expected [14].

(a)

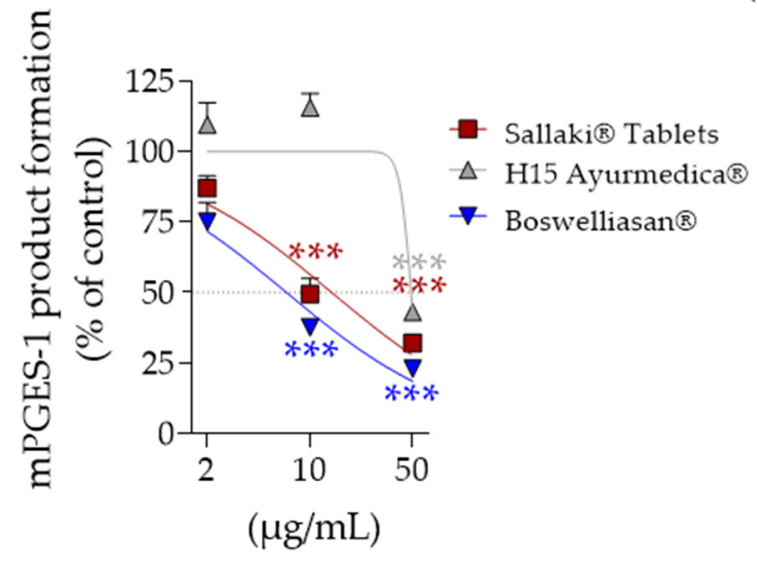

(b)

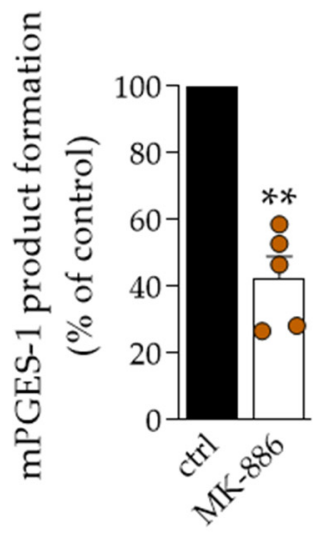

Figure 3. Effects of frankincense-based remedies on mPGES-1 activity. (a) Microsomal preparations of IL-1 $\beta$-stimulated A549 cells were incubated with 2, 10, or $50 \mu \mathrm{g} / \mathrm{mL}$ of frankincense-based remedies or vehicle $(0.1 \% \mathrm{EtOH})$ for $15 \mathrm{~min}$ at $4{ }^{\circ} \mathrm{C}$. The reaction was started with $20 \mu \mathrm{M} \mathrm{PGH}$. After $1 \mathrm{~min}$ at $4{ }^{\circ} \mathrm{C}$, the reaction was terminated using a stop solution containing $\mathrm{FeCl}_{2}$ and $11 \beta-\mathrm{PGE}_{2}$. Formed $\mathrm{PGE}_{2}$ was purified by SPE and analyzed using RP-HPLC. Data, expressed as percentage of control, are given as mean \pm S.E.M., $n=5$; repeated measures ANOVA + Dunnett post hoc test with raw data; ** $p<0.01$; ${ }^{* * *} p<0.001$ vs. vehicle. (b) MK-886 $(10 \mu \mathrm{M})$ was used as positive control under the same experimental conditions as above. Paired $t$-test; ${ }^{* *} p<0.01$ vs. vehicle. 


\subsection{Modulation of Lipid Mediator Production in Exotoxin-Stimulated Neutrophils by Frankincense-Based Remedies}

Next, we assessed how the frankincense-based preparations affect 5-LOX activity in intact human neutrophils that are major producers of leukotrienes [15], challenged with Staphylococcus aureus-conditioned medium (SACM) containing exotoxins for eliciting 5-LOX product formation [16]. Freshly isolated neutrophils from human blood were pre-incubated with the frankincense-based remedies for $15 \mathrm{~min}$ prior to addition of $1 \%$ SACM for $90 \mathrm{~min}$ at $37^{\circ} \mathrm{C}$. Formed 5-LOX products $\left(\mathrm{LTB}_{4}\right.$ and its trans-isomer and 5-HETE) were assessed by UPLC-MS-MS as reported [16]. In agreement with the results using isolated 5-LOX, "Sallaki ${ }^{\circledR}$ Tablets" and "BOSWELLIASAN ${ }^{\circledR}$ " caused potent suppression of 5-LOX product formation with $\mathrm{IC}_{50}$ of 15 and $7.5 \mu \mathrm{g} / \mathrm{mL}$, respectively, while "H15 Ayurmedica ${ }^{\circledR}$ " was less efficient $\left(\mathrm{IC}_{50}=39 \mu \mathrm{g} / \mathrm{mL}\right.$ ) (Figure $\left.4 \mathrm{a}\right)$. Notably, the well-known 5-LOX-stimulatory effects in neutrophils at low frankincense extract concentration [17] were evident for "Sallaki ${ }^{\circledR}$ Tablets" and "BOSWELLIASAN ${ }^{\circledR}$ " (at $2 \mu \mathrm{g} / \mathrm{mL}$ ) but not for "H15 Ayurmedica ${ }^{\circledR}$ " (Figure 4a); zileuton at $3 \mu \mathrm{M}$ markedly suppressed 5-LOX product formation as well (Figure $4 \mathrm{~b}$ ). Furthermore, 12-HETE formation was concentration-dependently elevated by "Sallaki ${ }^{\circledR}$ Tablets" and "BOSWELLIASAN ${ }^{\circledR}$ ", as expected based on an AKBA-mediated regiospecificity shift of 5-LOX towards a 12-lipoxygenating enzyme [18], but much less by "H15 Ayurmedica ${ }^{\circledR}$ " (Figure 4c) where AKBA contents are minute (see Table 1).

(a)

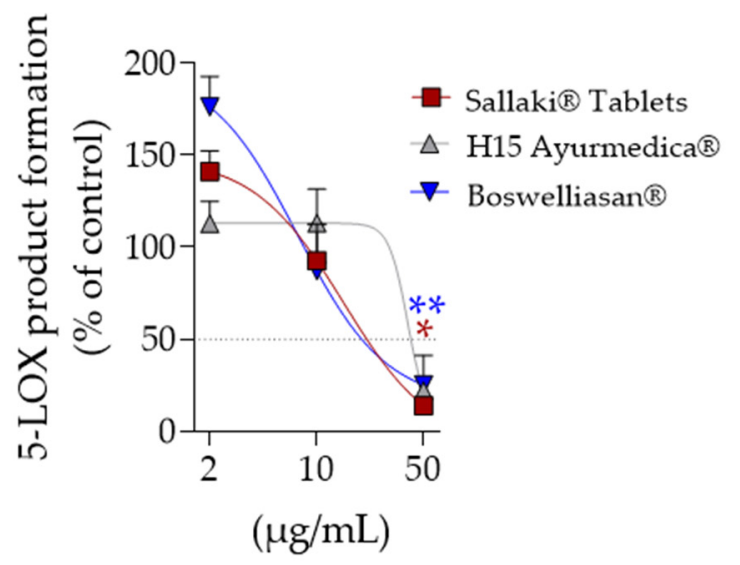

(b)

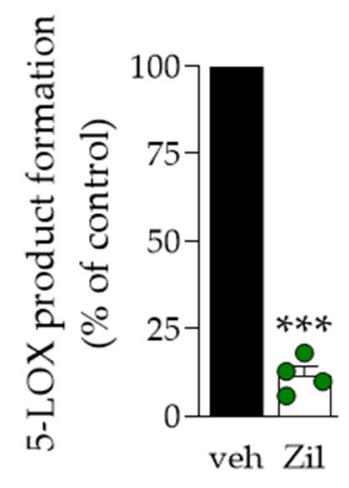

(c)

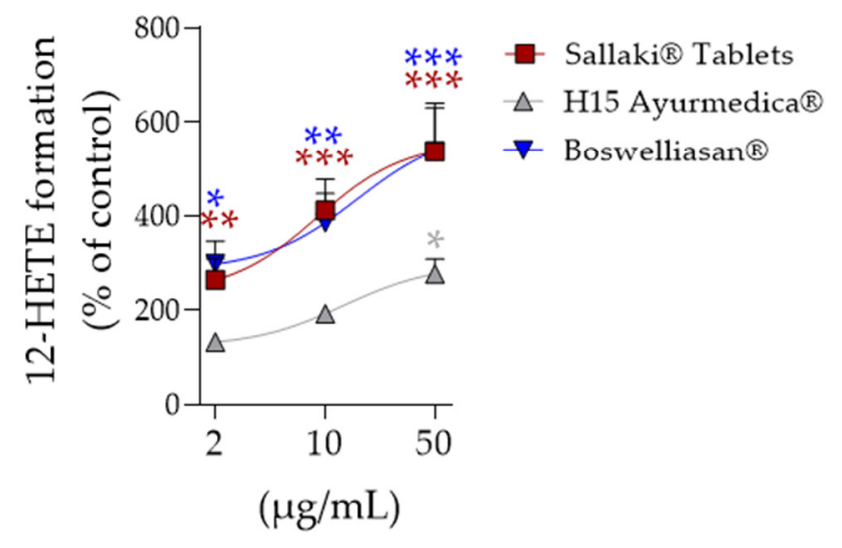

Figure 4. Modulation of LOX product formation in exotoxin-stimulated neutrophils by frankincensebased remedies. Human neutrophils $\left(5 \times 10^{6}\right.$ cells $\left./ \mathrm{mL}\right)$ were incubated with 2,10 , or $50 \mu \mathrm{g} / \mathrm{mL}$ of frankincense-based remedies, $3 \mu \mathrm{M}$ zileuton, or vehicle $(0.1 \% \mathrm{EtOH})$ for $15 \mathrm{~min}$ at $37^{\circ} \mathrm{C}$. LOX product 
formation was induced by addition of SACM $(1 \%)$ and $\mathrm{CaCl}_{2}(1 \mathrm{mM})$ for $90 \mathrm{~min}$ at $37^{\circ} \mathrm{C}$. Formed lipid mediators (LM) were isolated by SPE and analyzed using UPLC-MS-MS. Data are means \pm S.E.M, $\mathrm{n}=4-5$ separate donors. (a) Inhibition of 5-LOX product formation (sum of tr-LTB ${ }_{4}$, etr-LTB $\mathrm{LTB}_{4}, 5$-HETE) by frankincense-based remedies. (b) Inhibition of 5-LOX product formation by zileuton $(3 \mu \mathrm{M})$ under the same conditions. (c) Stimulation of 12-LOX product formation (12-HETE) by frankincense-based remedies under the same conditions. Data, expressed as percentage of vehicle control $(=100 \%)$, are given as mean \pm S.E.M., ${ }^{*} p<0.05 ;{ }^{* *} p<0.01 ;{ }^{* * *} p<0.001$ vs. vehicle. ANOVA + Dunnett post hoc test with logarithmized raw data; zileuton $(3 \mu \mathrm{M})$ was used as positive control under the same experimental conditions as above. T-test; ${ }^{* *} p<0.001$ vs. vehicle; outliers were identified by using Grubb's outlier test, $\alpha=0.05$.

\subsection{Effects of Frankincense-Based Remedies on Pro-Inflammatory Cytokine Secretion}

For analysis of the effects of the remedies on pro-inflammatory cytokine release [19], primary monocytes isolated from human peripheral blood were pre-incubated with the test items for $30 \mathrm{~min}$ and then stimulated with LPS $(10 \mathrm{ng} / \mathrm{mL})$ for $4 \mathrm{~h}$ to measure TNF- $\alpha$ or for $18 \mathrm{~h}$ to measure IL- $1 \beta$ and IL- 6 release in the cell supernatant by ELISA; dexamethasone $(100 \mathrm{nM})$ was used as reference drug. None of the frankincense-based remedies significantly blocked the release of IL- 6 or TNF- $\alpha$, while dexamethasone suppressed both responses, especially IL-6 release (Figure 5). Of interest, "BOSWELLIASAN ${ }^{\circledR ”}$ concentrationdependently inhibited the secretion of IL- $1 \beta$ with $55 \%$ suppression at $50 \mu \mathrm{g} / \mathrm{mL}$; "Sallaki ${ }^{\circledR}$ Tablets" and "H15 Ayurmedica ${ }^{\circledR}$ " were not significantly active at the highest test concentration of $50 \mu \mathrm{g} / \mathrm{mL}$, and dexamethasone $(100 \mathrm{nM})$ reduced IL-1 $\beta$ release by $90 \%$ (Figure 5).
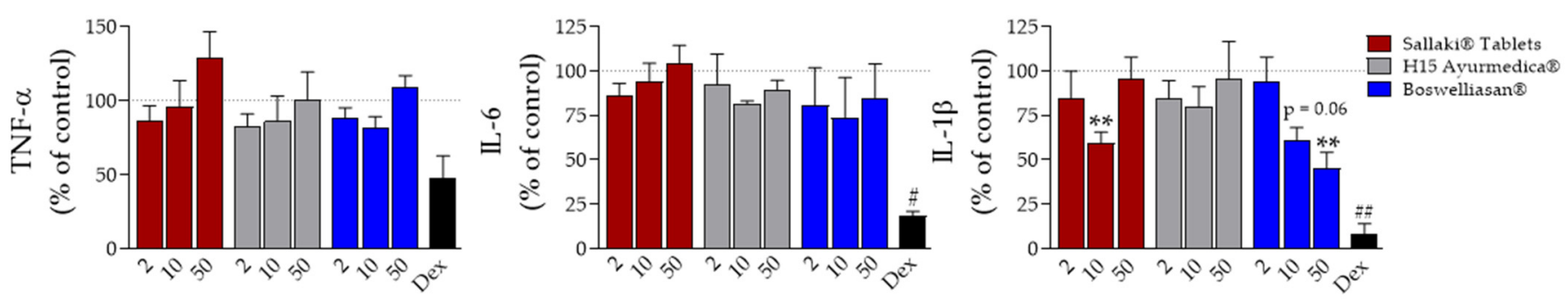

Figure 5. Effects of frankincense-based remedies on cytokine production. Freshly isolated human monocytes $\left(1.5 \times 10^{6} / \mathrm{mL}\right)$ were pre-incubated with 2,10 , or $50 \mu \mathrm{g} / \mathrm{mL}$ of frankincense-based remedies, $100 \mathrm{nM}$ dexamethasone, or vehicle $(0.1 \%$ $\mathrm{EtOH})$ for $30 \mathrm{~min}$. Cells were then stimulated with LPS $(10 \mathrm{ng} / \mathrm{mL})$ for $4 \mathrm{~h}(\mathrm{TNF}-\alpha)$ or $18 \mathrm{~h}$ (IL-6, IL-1 $\beta)$. Determination of cytokines in the supernatants was performed using ELISA. Data, expressed as percentage of control, are given as mean \pm S.E.M., $\mathrm{n}=3$ for TNF- $\alpha$ and IL-6, and $\mathrm{n}=5$ for IL-1 $\beta$. Statistics: Repeated measures ANOVA + Dunnett post hoc test with raw data. $\# p<0.05 ;{ }^{* *}, \# \# p<0.01$ vs. vehicle.

\section{Discussion}

Here, we studied three frequently used frankincense-based remedies for their BA content and in parallel for inhibition of the key targets of BAs, namely 5-LOX and mPGES1 , as well as for suppression of pro-inflammatory LT and cytokine production in human primary leukocytes. We found considerable differences in the quality between the analyzed products, in terms of BA content as well as regarding their pharmacological efficiency. To our surprise "H15 Ayurmedica ${ }^{\circledR}$ " revealed only trace amounts of the characteristic BAs, that is, KBA, $\mathrm{AKBA}, \alpha \mathrm{BA}, \mathrm{A} \alpha \mathrm{BA}, \beta \mathrm{BA}$, and $\mathrm{A} \beta \mathrm{BA}$, and accordingly, the pharmacological activities in vitro were much less efficient as compared to "BOSWELLIASAN ${ }^{\circledR}$ " and "Sallaki ${ }^{\circledR}$ Tablets". In fact, these two products contain substantial amounts of BAs and display potent pharmacological effects in vitro that might be beneficial for treatment of inflammatory diseases. Thus, the observed dual inhibition of 5-LOX and mPGES-1 along with a shift of the LM class switch towards 12/15-LOX products by the extracts is of pivotal interest with high therapeutic potential, representing a pharmacological concept which 
is currently pursued as a novel and innovative approach in the therapy of inflammatory diseases [20-22].

In general, ingredients of dietary supplements are presented in the same order as the corresponding amount in the product. Since the amount of Boswellia serrata extract per capsule is not declared on the label and based on the fact that Boswellia serrata is listed as penultimate ingredient prior to titanium dioxide used as colorant for the capsule shell, substantial amounts of Boswellia serrata extract were not expected in this product. Nevertheless, the fact that only traces of BAs could be detected fell far short of expectations. This might be attributed to inadequate extract preparation or to the application of another Boswellia species such as Boswellia frereana that contains only traces of BAs and other triterpene acids like lupeolic acid [13].

There is also a striking difference between the ratios of the individual BAs in the tested products. Hence, Boswellia serrata extracts contained in "Sallaki ${ }^{\circledR}$ Tablets" and "BOSWELLIASAN ${ }^{\circledR}$ " in contrast to "H15 Ayurmedica ${ }^{\circledR}$ " are characterized by a higher amount of non-acetylated/non-ketylated BAs compared to the acetylated ones. This is clearly reflected in the ratios of the respective BAs. Thus, in both "Sallaki ${ }^{\circledR}$ Tablets" and

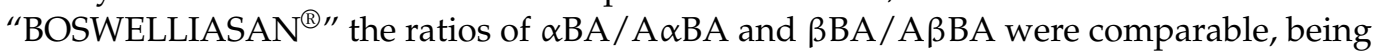
2.66 and 2.11 for $\alpha \mathrm{BA} / \mathrm{A} \alpha \mathrm{BA}$ in "Sallaki ${ }^{\circledR}$ Tablets" and "BOSWELLIASAN ${ }^{\circledR \text { ", }}$ respectively, as well as 2.05 and 1.7 for $\beta B A / A \beta B A$ "Sallaki ${ }^{\circledR}$ Tablets" and "BOSWELLIASAN ${ }^{\circledR ”}$ ", respectively. In addition, the total sum of the determined BAs make up around $31 \%$ of the applied Boswellia serrata extract in both products. This corresponds to the known distribution and amounts of BAs in Boswellia serrata extracts [12,23]. On the other hand, this distribution in the individual BAs could not be detected in "H15 Ayurmedica ${ }^{\circledR}$ " raising further questions with regard to the origin of the extract applied in "H15 Ayurmedica ${ }^{\circledR}$ ".

Last but not least, it should be noticed that the determined total sum of the analyzed BAs may correspond to the declared amount of $400 \mathrm{mg}$ Boswellia serrata for "Sallaki ${ }^{\circledR}$ Tablets" and "H15 Ayurmedica ${ }^{\circledR}$ " or $300 \mathrm{mg}$ Boswellia serrata extract for "BOSWELLIASAN ${ }^{\circledR \text { " on }}$ the label. Note that for technical reasons, we analyzed $300 \mathrm{mg}$ of the Boswellia serrata extract contained in the product "BOSWELLIASAN ${ }^{\circledR}$ " that is actually composed of $400 \mathrm{mg}$ of this extract. Finally, different analytical methods may result in different BA contents depending on whether HPLC, a titration method, or a very specific LC-MS/MS method was applied as in the present case [24-27].

BAs display a multitude of pharmacological activities [4]. 5-LOX and mPGES-1 are well-defined molecular targets that directly bind BAs and are inhibited by these triterpene acids $[4,18,28,29]$. mPGES- 1 is an inducible enzyme in the biosynthesis of pro-inflammatory $\mathrm{PGE}_{2}$ from COX-2-derived $\mathrm{PGH}_{2}$, and is proposed as an alternative drug target to COX enzymes that are blocked by NSAIDs, to effectively and safely intervene with inflammatory disorders [30,31]. In fact, lipophilic extracts of various Boswellia species blocked mPGES1 activity [32] and the abundant $\beta$-BA efficiently inhibited $\mathrm{PGE}_{2}$ under inflammatory conditions in vivo after oral application to rats [29]. Recently, we showed that AKBA binds an allosteric site in 5-LOX thereby shifting the regiospecificity towards a 12-lipoxygenating enzyme, which in neutrophils led to decreased LT and 5-HETE levels but increased the amounts of 12/15-LOX products and elevated anti-inflammatory specialized pro-resolving mediators (SPM) in 5-LOX-transfected HEK cells [18]. Such a pattern was also revealed in the present study for "Sallaki ${ }^{\circledR}$ Tablets" and "BOSWELLIASAN ${ }^{\circledR}$ " that inhibited the formation of LTs and 5-HETE in human primary neutrophils that had been challenged by physiological relevant bacterial exotoxins [16] and at the same time, shifted AA conversion towards 12-HETE, as observed for AKBA [18]. BAs were shown to inhibit constitutively activated NF-kappaB signaling by blocking IkappaB kinase activity [33], which might underly the suppressive effects on pro-inflammatory cytokine release [19]. Note that the suppression of cytokine release from LPS-stimulated monocytes was much less sensitive to the frankincense products as compared to LT formation, implying a subordinated effect as compared to interference with LM formation. Future analysis on these products may 
also reveal additional anti-inflammatory effects such as the observed interference with the formation of reactive oxygen species [34,35].

It is tempting to speculate that "Sallaki ${ }^{\circledR}$ Tablets" and "BOSWELLIASAN ${ }^{\circledR}$ " may act as LM class switch inducer also in inflammation models in vivo, that is, to lower LT and $\mathrm{PGE}_{2}$ levels but increase the amounts of SPM. There is a current trend towards concepts of immunoresolvent therapies in inflammation in order to support resolution [36], especially by exploiting SPM rather than blocking the inflammatory process using glucocorticoids or NSAIDs that act as immunosuppressants with severe side effects [21,22]. Our findings support the application of high-quality frankincense-based remedies in inflammatory diseases to effectively push the LM class switch towards SPM in order to promote endogenous programs of inflammation resolution without immunosuppression. Future studies with appropriate experimental models and test systems will reveal if frankincense-based remedies may act in this respect and foster SPM formation.

Finally, we point out that the strong promises of frankincense-based products in the therapy of many diseases are mainly built upon experience-based medicine, such as case reports, rather than on evidence-based medicine. Thus, there are limitations with respect to efficacy in disease treatment, for example in oncology, where the therapeutic potential for cancer treatment is still speculative and well-designed clinical studies are required to validate the clinical usefulness $[6,7]$.

\section{Materials and Methods}

\subsection{Materials}

"Sallaki ${ }^{\circledR}$ Tablets" (charge AB18024), “H15 Ayurmedica ${ }^{\circledR}$ (charge 171), and "BOSWEL LIASAN ${ }^{\circledR}$ " (charge HBPC11) are commercially available by various suppliers. KBA, AKBA, $\alpha B A, A \alpha B A, \beta B A$, and $A \beta B A$ (purity $>99 \%$ ) were purchased from Phytoplan (Heidelberg, Germany). Methanol of LC/MS quality was purchased from Carl Roth GmbH (Karlsruhe, Germany) and ammonium formate from Sigma Aldrich (Karlsruhe, Germany). The applied water was purified by using a Milli-Q-purification system from Merck Millipore Corporation (Bedford, MA, USA). All other chemicals and reagents were obtained from Sigma-Aldrich (Munich, Germany), unless stated otherwise.

\subsection{Standard Preparation}

Stock standard solutions of each BA were prepared by weighing into a $20 \mathrm{~mL}$ volumetric flask $20 \mathrm{mg}$ of each BA standard and diluting it with $20 \mathrm{~mL}$ methanol to yield a concentration of $1 \mathrm{mg} / \mathrm{mL}$ of each BA. Mixed spike solutions were prepared by mixing the appropriate amount of each BA stock standard solution with methanol to yield spike solutions K1 $(4 \mu \mathrm{g} / \mathrm{mL}), \mathrm{K} 2(12 \mu \mathrm{g} / \mathrm{mL})$, and $\mathrm{K} 3(24 \mu \mathrm{g} / \mathrm{mL})$.

\subsection{Sample Preparation}

For "Sallaki ${ }^{\circledR}$ Tablets" and "BOSWELLIASAN ${ }^{\circledR ”, ~ t h e ~ c o n t e n t s ~ o f ~ t h e ~ t a b l e t s / c a p s u l e s ~}$ were pulverized and well mixed. An equivalent to $100 \mathrm{mg}$ extract was weighed in a $50 \mathrm{~mL}$ centrifuge tube (Eco, PP, Roth, Art. AN78.1). In the case of the "H15 Ayurmedica ${ }^{\circledR}$ " which is an oily substance, 1 capsule was carefully cut in half in a $50 \mathrm{~mL}$ centrifuge glass with a scalpel. Then, $20 \mathrm{~mL}$ of methanol (volumetric pipette) and two glass pearls were added to each product and shaken for $60 \mathrm{~min}$ at $200 \mathrm{rpm}$ on a vertical shaker. Afterwards, the samples were treated in an ultrasonic bath for $30 \mathrm{~min}$ and centrifuged for $10 \mathrm{~min}$ at $2000 \mathrm{rpm}$. Four aliquots of $100 \mu \mathrm{L}$ (or $25 \mu \mathrm{L}$ depending on the content in the oil capsules) of the clear supernatant were then transferred into four $10 \mathrm{~mL}$ volumetric flasks. Three of these aliquots for each product were diluted with $1 \mathrm{~mL}$ of the three spike solutions K1, K2, K3, respectively, to yield three differently spiked samples. To one aliquot, no spike solution was added. Finally, $20 \mu \mathrm{L}$ of each sample solution was injected into the chromatographic system. 


\subsection{LC-MS/MS Method}

The BA content was determined according to a previously developed sensitive LCMS/MS method. In brief, LC was performed on an Agilent 1200 series consisting of a gradient pump with vacuum degasser, an autosampler, and a column oven. A Hypersil BDS RP C18 column $(100 \times 4 \mathrm{~mm} ; 3 \mu \mathrm{m}$; Thermo scientific) and an upstream Gemini security guard cartridge ( $4 \times 3 \mathrm{~mm}$; Phenomenex, Germany) were used for chromatography. Separation was achieved using a gradient program starting with $90 \%$ mobile phase A (methanol: water 90:10, $400 \mathrm{mg} / \mathrm{L}$ ammonium formate) and 10\% mobile phase B (methanol: water $80: 20,400 \mathrm{mg} / \mathrm{L}$ ammonium formate) rising to $100 \%$ mobile phase A within $20 \mathrm{~min}$. This was kept constant for $14 \mathrm{~min}$ before returning to the initial conditions during $1 \mathrm{~min}$. The total run time was $35 \mathrm{~min}$ at a flow rate of $0.4 \mathrm{~mL} / \mathrm{min}$. The column oven was set to $40^{\circ} \mathrm{C}$ and the autosampler was kept at room temperature.

MS analysis was performed in the negative single ion mode (SIM, AKBA $m / z$ 511.5, $\mathrm{A} \alpha \mathrm{BA}$ and $\mathrm{A} \beta \mathrm{BA} m / z$ 497.4, KBA $m / z 469.3, \alpha \mathrm{BA}$ and $\beta \mathrm{BA} m / z$ 455.5) on an Agilent Triple Quadrupole LC/MS 6410 series (Agilent Technologies, Waldbronn, Germany) equipped with an Electro Spray Ionization source (ESI). Dwell time was chosen to be $200 \mathrm{~ms}$. The Mass Hunter software was used for data acquisition and processing.

A standard addition method at three concentration levels $(4 \mu \mathrm{g} / \mathrm{mL}, 12 \mu \mathrm{g} / \mathrm{mL}$, and $24 \mu \mathrm{g} / \mathrm{mL}$ ) was chosen for the quantification of BAs. The resulting plots of concentration versus peak area were linear with $R^{2}>0.9984$ for all BAs. The percent recovery, determined by comparing the calculated amounts of the BAs with the real amount spiked to the samples, ranged from $96.87 \%$ to $100.03 \%$ for KBA, $99.94 \%$ to $100.11 \%$ for AKBA, $99.89 \%$ to $100.56 \%$ for $\beta \mathrm{BA}, 98.43 \%$ to $100.87 \%$ for $\alpha \mathrm{BA}, 99.98 \%$ to $100.01 \%$ for $\mathrm{A} \beta \mathrm{BA}$, and $97.70 \%$ to $101.28 \%$ for $\mathrm{A} \alpha \mathrm{BA}$. The reproducibility in terms of relative standard deviation at each level ranged from $0.24 \%$ to $2.12 \%$ for $\mathrm{KBA}, 0.2 \%$ to $1.83 \%$ for $\mathrm{AKBA}, 0.48 \%$ to $4.39 \%$ for $\beta \mathrm{BA}$, $0.3 \%$ to $2.72 \%$ for $\alpha \mathrm{BA}, 0.29 \%$ to $2.64 \%$ for $\mathrm{A} \beta \mathrm{BA}$, and $0.27 \%$ to $2.46 \%$ for $\mathrm{A} \alpha \mathrm{BA}$.

\subsection{Expression, Purification, and Activity Assay of Human Recombinant 5-LOX}

Human recombinant 5-LOX was expressed in E. coli BL21 (DE3) transformed with pT35LO plasmid, and purification of 5-LOX was performed as described before [37]. Briefly, E. coli were lysed in $50 \mathrm{mM}$ triethanolamine/ $\mathrm{HCl} \mathrm{pH} 8.0$ plus EDTA $(5 \mathrm{mM})$, soybean trypsin inhibitor $(60 \mu \mathrm{g} / \mathrm{mL})$, phenylmethanesulphonyl fluoride $(1 \mathrm{mM})$, dithiothreitol $(1 \mathrm{mM})$, and lysozyme $(1 \mathrm{mg} / \mathrm{mL})$ and then sonicated $(3 \times 15 \mathrm{~s})$. The homogenate was then centrifuged at $40,000 \times g$ for $20 \mathrm{~min}$ at $4{ }^{\circ} \mathrm{C}$. 5-LOX in the supernatant was partially purified by affinity chromatography on an ATP-agarose column (Sigma Aldrich, Munich, Germany). Semi-purified 5-LOX was diluted in PBS containing EDTA $(1 \mathrm{mM})$ and immediately used for activity assays.

5-LOX $(0.5 \mu \mathrm{g} / \mathrm{mL})$ was pre-incubated with the test items for $15 \mathrm{~min}$ at $4{ }^{\circ} \mathrm{C}$. 5-LOX product formation was initiated by addition of $2 \mathrm{mM} \mathrm{CaCl}_{2}$ plus $20 \mu \mathrm{M}$ arachidonic acid. After $10 \mathrm{~min}$ at $37^{\circ} \mathrm{C}$, the reaction was terminated by adding $1 \mathrm{~mL}$ ice-cold methanol. Formed 5-LOX metabolites (all-trans isomers of $\mathrm{LTB}_{4}$ and 5-hydro(peroxy)eicosatetraenoic acid (H(P)ETE)) were analyzed by RP-HPLC as described [38].

\subsection{Induction of mPGES-1 in A549 Cells, Isolation of Microsomes, and Determination of mPGES-1 Activity}

Microsomes of IL-1 $\beta$-activated A549 cells were prepared and mPGES- 1 activity determined as described [29]. In brief, cells were treated with IL-1 $\beta(1 \mathrm{ng} / \mathrm{mL})$ at $37^{\circ} \mathrm{C}$ and $5 \% \mathrm{CO}_{2}$, harvested after $72 \mathrm{~h}$, and frozen in liquid nitrogen. After reuptake of the cells in ice-cold homogenization buffer $(0.1 \mathrm{M}$ potassium phosphate buffer $\mathrm{pH} 7.4,1 \mathrm{mM}$ phenylmethanesulphonyl fluoride, $60 \mu \mathrm{g} / \mathrm{mL}$ soybean trypsin inhibitor, $1 \mu \mathrm{g} / \mathrm{mL}$ leupeptin, $2.5 \mathrm{mM}$ glutathione, and $250 \mathrm{mM}$ sucrose) and incubation for $15 \mathrm{~min}$, cells were sonicated on ice $(3 \times 20 \mathrm{~s})$ and subjected to differential centrifugation at $10,000 \times g$ for $10 \mathrm{~min}$ and $174,000 \times \mathrm{g}$ for $1 \mathrm{~h}$ at $4{ }^{\circ} \mathrm{C}$. The microsomal fraction (pellet) was resuspended in homogenization buffer, analyzed for its protein content using a protein assay kit (Bio-Rad 
laboratories $\mathrm{GmbH}$, Munich, Germany), and diluted in potassium phosphate buffer (0.1 M, $\mathrm{pH}$ 7.4) containing $2.5 \mathrm{mM}$ glutathione. After pre-incubation with the test items for $15 \mathrm{~min}$ at $4{ }^{\circ} \mathrm{C}$, the reaction $\left(100 \mu \mathrm{L}\right.$ total volume) was initiated by the addition of $20 \mu \mathrm{M} \mathrm{PGH}_{2}$ and terminated after 1 min by the addition of $100 \mu \mathrm{L}$ stop solution $\left(40 \mathrm{mM} \mathrm{FeCl}_{2}, 80 \mathrm{mM}\right.$ citric acid, and $10 \mu \mathrm{M}$ of $11 \beta-\mathrm{PGE}_{2}$ as internal standard). $\mathrm{PGE}_{2}$ was separated by solid phase extraction on RP-C18 material using acetonitrile $(200 \mu \mathrm{L})$ as eluent, and analyzed by RPHPLC ( $30 \%$ acetonitrile aqueous, $0.007 \%$ TFA $(v / v)$, Nova-Pak ${ }^{\circledR}$ C18 column, $5 \times 100 \mathrm{~mm}$, $4 \mu \mathrm{m}$ particle size, flowrate $1 \mathrm{~mL} / \mathrm{min}$ ) with $\mathrm{UV}$ detection at $195 \mathrm{~nm}$.

\subsection{Isolation of Human Leucocytes}

Leucocyte concentrates from freshly withdrawn peripheral blood of adult healthy donors were provided by the Institute of Transfusion Medicine of the University Hospital Jena, Germany. The experimental protocol was approved by the ethical committee of the University Hospital Jena. All methods were performed in accordance with the relevant guidelines and regulations. Neutrophils and monocytes were immediately isolated as described before [39]. In brief, cells were isolated by dextran sedimentation and Ficoll-Histopaque 1077-1 (Sigma-Aldrich) density centrifugation. To purify neutrophils, the remaining erythrocytes were removed by hypotonic lysis. Neutrophils were finally resuspended in PBS pH 7.4 plus $1 \mathrm{mg} / \mathrm{mL}$ glucose at the cell density of $5 \times 10^{6}$ cells $/ \mathrm{mL}$. Monocytes were separated from peripheral blood mononuclear cells by adherence to cell culture flasks (Greiner Bio-one, Frickenhausen, Germany) for $1 \mathrm{~h}\left(37^{\circ} \mathrm{C}, 5 \% \mathrm{CO}_{2}\right)$, followed by cell scraping and resuspension in RPMI 1640 supplemented with $5 \%$ fetal calf serum, $2 \mathrm{mmol} / \mathrm{L}$ L-glutamine (Biochrom/Merck, Berlin, Germany), and $100 \mathrm{U} / \mathrm{mL}$ penicillin; $100 \mu \mathrm{g} / \mathrm{mL}$ streptomycin (Biochrom/Merck).

\subsection{Preparation of Exotoxin-Containing Staphylococcus Aureus-Conditioned Medium (SACM)}

A single colony of Staphylococcus aureus (strain 6850) grown for $24 \mathrm{~h}$ at $37^{\circ} \mathrm{C}$ on Columbia-agar plates containing 5\% sheep blood (Altmann Analytic, Munich, Germany) was picked and inoculated in $50 \mathrm{~mL}$ of brain heart infusion broth (BHI, Sigma-Aldrich) for a further $24 \mathrm{~h}$ at $37^{\circ} \mathrm{C}$ under shaking $\left(250 \mathrm{rpm}\right.$ ). The $\mathrm{OD}_{600}$ was adjusted to 0.05 by dilution with $\mathrm{BHI}$ and $50 \mathrm{~mL}$ of the corresponding solution was cultivated for another $24 \mathrm{~h}$. Finally, $15 \mathrm{~mL}$ were centrifuged for $10 \mathrm{~min}$ at $3350 \times \mathrm{g}$ and sterile filtered using a $0.22 \mu \mathrm{m}$ PVDF syringe filter (Carl Roth $\mathrm{GmbH})$.

\subsection{Analysis of LOX Product Formation in Human Neutrophils}

Human neutrophils $\left(5 \times 10^{6} / \mathrm{mL}\right)$ were preincubated with a test item or vehicle $(0.1 \%$ $\mathrm{EtOH})$ for $15 \mathrm{~min}$ at $37^{\circ} \mathrm{C}$. The production of LOX products was induced by addition of SACM $(1 \%)$ and $\mathrm{CaCl}_{2}(1 \mathrm{mM})$. After $90 \mathrm{~min}$ at $37^{\circ} \mathrm{C}$, the reaction was stopped with $2 \mathrm{~mL}$ ice-cold $\mathrm{MeOH}$ containing deuterium-labeled internal standards $\mathrm{d}_{8}$-5S-HETE and $\mathrm{d}_{4}-\mathrm{LTB}_{4}\left(200 \mathrm{nM}\right.$ each), and $10 \mu \mathrm{M} \mathrm{d}_{8}$-AA (Cayman Chemical/Biomol GmbH, Hamburg, Germany). Sample preparation was conducted as described previously [40]. In brief, samples were kept at $-20^{\circ} \mathrm{C}$ overnight to allow protein precipitation. After centrifugation $\left(1200 \times g, 4{ }^{\circ} \mathrm{C}, 10 \mathrm{~min}\right)$, supernatants were transferred to $7 \mathrm{~mL}$ acidified $\mathrm{H}_{2} \mathrm{O}(\mathrm{pH} 3.5$, $\mathrm{HCl}$ ). The LOX products in these samples were purified by solid phase extraction (SPE). Solid-phase C18 cartridges (Sep-Pak ${ }^{\circledR}$ Vac $6 c c 500$ mg / 6 mL C18; Waters, Milford, MA) were equilibrated with $6 \mathrm{~mL} \mathrm{MeOH}$ and $6 \mathrm{~mL} \mathrm{H}_{2} \mathrm{O}$. Next, samples were loaded onto the columns. After washing with $6 \mathrm{~mL} \mathrm{H}_{2} \mathrm{O}$ and additional $6 \mathrm{~mL} n$-hexane, LMs were eluted with $6 \mathrm{~mL}$ methyl formate. Finally, the samples were brought to dryness using an evaporation system (TurboVap LV; Biotage, Uppsala, Sweden) and resuspended in $100 \mu \mathrm{L}$ methanol-water $(50 / 50, v / v)$ for ultraperformance liquid chromatography-tandem mass spectrometry measurements (UPLC-MS-MS). LOX product profiling was conducted by means of an Acquity ${ }^{\mathrm{TM}}$ UPLC system (Waters, Milford, MA, USA) and a QTRAP 5500 Mass Spectrometer (ABSciex, Darmstadt, Germany) equipped with a Turbo $V^{\text {TM }}$ Source and electrospray ionization. LM were eluted using an ACQUITY UPLC ${ }^{\circledR}$ BEH C18 column 
$\left(1.7 \mu \mathrm{m}, 2.1 \times 100 \mathrm{~mm}\right.$; Waters, Eschborn, Germany) at $50{ }^{\circ} \mathrm{C}$ with a flow rate of $0.3 \mathrm{~mL} / \mathrm{min}$ and a mobile phase consisting of methanol-water-acetic acid of 42:58:0.01 $(v / v / v)$ that was ramped to 86:14:0.01 ( $v / v / v)$ over $12.5 \mathrm{~min}$ and then to 98:2:0.01 $(v / v / v)$ for $3 \mathrm{~min}$. The QTrap 5500 was operated in negative ionization mode using scheduled multiple reaction monitoring (MRM) coupled with information-dependent acquisition. Optimized LM parameters (CE, collision energy; EP, entrance potential; DP, declustering potential; CXP, collision cell exit potential) were adopted [40], and the curtain gas pressure was set to 35 psi. The retention time and diagnostic ions for each LM were confirmed by means of an external standard (Cayman Chemical/Biomol GmbH, Hamburg, Germany). Quantification was achieved by calibration curves for each LM.

\subsection{Determination of Cytokine Levels}

Monocytes $\left(1.5 \times 10^{6} / \mathrm{mL}\right)$ were resuspended in monocyte medium (RPMI 1640 supplemented with 5\% fetal calf serum, $2 \mathrm{mmol} / \mathrm{L}$ L-glutamine (Biochrom/Merck, Berlin, Germany), $100 \mathrm{U} / \mathrm{mL}$ penicillin, and $100 \mu \mathrm{g} / \mathrm{mL}$ streptomycin (Biochrom/Merck)). After $1.5 \mathrm{~h}$ at $37^{\circ} \mathrm{C}$ and $5 \% \mathrm{CO}_{2}$, test items or vehicle were added for $30 \mathrm{~min}$. Then, cells were stimulated with $10 \mathrm{ng} / \mathrm{mL}$ LPS for $4 \mathrm{~h}$ (TNF- $\alpha$ ) or $18 \mathrm{~h}$ (IL-1 $\beta$ and IL-6). For measurement of extracellular cytokine levels, the supernatants were collected and centrifuged $(2000 \times g$, $\left.4{ }^{\circ} \mathrm{C}, 10 \mathrm{~min}\right)$. Cytokines in the supernatant were analyzed by in-house-made ELISA using capture and detection antibodies from R\&D Systems (Abington, UK).

Author Contributions: Conceptualization, M.A.-T. and O.W.; methodology, M.W. and J.M.; validation, M.W.; formal analysis, F.B. and J.M.; investigation, F.B. and J.M.; resources, J.E.; data curation, M.W.; writing-original draft preparation, M.W., M.A.-T., and O.W.; writing—review and editing, F.B., M.W., J.M., M.A.-T., and O.W.; supervision, M.A.-T. and O.W.; project administration, O.W.; funding acquisition, J.E. and O.W. All authors have read and agreed to the published version of the manuscript.

Funding: This research was funded by Heidelberg-Apotheke/AureliaSan GmbH. The APC was funded by Friedrich-Schiller-University Jena.

Institutional Review Board Statement: The study was conducted according to the guidelines of the Declaration of Helsinki and approved by the Institutional Review Board of University Hospital Jena (5050-01/17, date: 3 March 2017).

Informed Consent Statement: Written informed consent was obtained from all subjects involved in the study.

Data Availability Statement: The data presented in this study are available on reasonable request from the corresponding author. The data are not publicly available due to privacy.

Acknowledgments: The authors thank Petra Wiecha, Katrin Fischer, Alrun Schumann, and Heidi Traber for expert technical assistance.

Conflicts of Interest: J.E. is the CEO of Heidelberg-Apotheke/AureliaSan GmbH and was funder of the study and provided resources. The funders had no role in the design of the study; in the collection, analyses, or interpretation of data; in the writing of the manuscript, or in the decision to publish the results.

\section{References}

1. Al-Yasiry, A.R.; Kiczorowska, B. Frankincense-therapeutic properties. Postepy Hig. Med. Dosw. 2016, 70, 380-391. [CrossRef]

2. Ernst, E. Frankincense: Systematic review. BMJ 2008, 337, a2813. [CrossRef]

3. Moussaieff, A.; Mechoulam, R. Boswellia resin: From religious ceremonies to medical uses, a review of in-vitro, in-vivo and clinical trials. J. Pharm Pharmacol 2009, 61, 1281-1293. [CrossRef] [PubMed]

4. Abdel-Tawab, M.; Werz, O.; Schubert-Zsilavecz, M. Boswellia serrata: An overall assessment of in vitro, preclinical, pharmacokinetic and clinical data. Clin. Pharmacokinet 2011, 50, 349-369. [CrossRef]

5. Ammon, H.P. Boswellic acids in chronic inflammatory diseases. Planta Med. 2006, 72, 1100-1116. [CrossRef]

6. Efferth, T.; Oesch, F. Anti-inflammatory and anti-cancer activities of frankincense: Targets, treatments and toxicities. In Seminars in Cancer Biology; Academic Press: Cambridge, MA, USA, 2020.

7. Kunnumakkara, A.B.; Banik, K.; Bordoloi, D.; Harsha, C.; Sailo, B.L.; Padmavathi, G.; Roy, N.K.; Gupta, S.C.; Aggarwal, B.B. Googling the Guggul (Commiphora and Boswellia) for Prevention of Chronic Diseases. Front. Pharmacol 2018, 9, 686. [CrossRef] [PubMed] 
8. Roy, N.K.; Parama, D.; Banik, K.; Bordoloi, D.; Devi, A.K.; Thakur, K.K.; Padmavathi, G.; Shakibaei, M.; Fan, L.; Sethi, G.; et al. An Update on Pharmacological Potential of Boswellic Acids against Chronic Diseases. Int J. Mol. Sci 2019, 20, 4101. [CrossRef] [PubMed]

9. Abdel-Tawab, M. Do We Need Plant Food Supplements? A Critical Examination of Quality, Safety, Efficacy, and Necessity for a New Regulatory Framework. Planta Med. 2018, 84, 372-393. [CrossRef]

10. Cohen, P.A.; Venhuis, B.J. Adulterated sexual enhancement supplements: More than mojo. JAMA Intern. Med. 2013, 173, 1169-1170. [CrossRef]

11. Rocha, T.; Amaral, J.S.; Oliveira, M. Adulteration of Dietary Supplements by the Illegal Addition of Synthetic Drugs: A Review. Compr. Rev. Food Sci. Food Saf. 2016, 15, 43-62. [CrossRef] [PubMed]

12. Meins, J.; Artaria, C.; Riva, A.; Morazzoni, P.; Schubert-Zsilavecz, M.; Abdel-Tawab, M. Survey on the Quality of the Top-Selling European and American Botanical Dietary Supplements Containing Boswellic Acids. Planta Med. 2016, 82, 573-579. [CrossRef] [PubMed]

13. Schmiech, M.; Lang, S.J.; Ulrich, J.; Werner, K.; Rashan, L.J.; Syrovets, T.; Simmet, T. Comparative Investigation of Frankincense Nutraceuticals: Correlation of Boswellic and Lupeolic Acid Contents with Cytokine Release Inhibition and Toxicity against Triple-Negative Breast Cancer Cells. Nutrients 2019, 11, 2341. [CrossRef] [PubMed]

14. Schaible, A.M.; Traber, H.; Temml, V.; Noha, S.M.; Filosa, R.; Peduto, A.; Weinigel, C.; Barz, D.; Schuster, D.; Werz, O. Potent inhibition of human 5-lipoxygenase and microsomal prostaglandin E(2) synthase-1 by the anti-carcinogenic and anti-inflammatory agent embelin. Biochem. Pharmacol. 2013, 86, 476-486. [CrossRef] [PubMed]

15. Surette, M.E.; Palmantier, R.; Gosselin, J.; Borgeat, P. Lipopolysaccharides prime whole human blood and isolated neutrophils for the increased synthesis of 5-lipoxygenase products by enhancing arachidonic acid availability: Involvement of the CD14 antigen. J. Exp. Med. 1993, 178, 1347-1355. [CrossRef] [PubMed]

16. Romp, E.; Arakandy, V.; Fischer, J.; Wolz, C.; Siegmund, A.; Loffler, B.; Tuchscherr, L.; Werz, O.; Garscha, U. Exotoxins from Staphylococcus aureus activate 5-lipoxygenase and induce leukotriene biosynthesis. Cell Mol. Life Sci. 2020, 77, 3841-3858. [CrossRef] [PubMed]

17. Safayhi, H.; Boden, S.E.; Schweizer, S.; Ammon, H.P. Concentration-dependent potentiating and inhibitory effects of Boswellia extracts on 5-lipoxygenase product formation in stimulated PMNL. Planta Med. 2000, 66, 110-113. [CrossRef] [PubMed]

18. Gilbert, N.C.; Gerstmeier, J.; Schexnaydre, E.E.; Borner, F.; Garscha, U.; Neau, D.B.; Werz, O.; Newcomer, M.E. Structural and mechanistic insights into 5-lipoxygenase inhibition by natural products. Nat. Chem. Biol. 2020, 16, 783-790. [CrossRef]

19. Syrovets, T.; Buchele, B.; Krauss, C.; Laumonnier, Y.; Simmet, T. Acetyl-boswellic acids inhibit lipopolysaccharide-mediated TNF-alpha induction in monocytes by direct interaction with IkappaB kinases. J. Immunol. 2005, 174, 498-506. [CrossRef]

20. Chiang, N.; Serhan, C.N. Specialized pro-resolving mediator network: An update on production and actions. Essays Biochem. 2020, 64, 443-462.

21. Serhan, C.N. Pro-resolving lipid mediators are leads for resolution physiology. Nature 2014, 510, 92-101. [CrossRef]

22. Serhan, C.N.; Levy, B.D. Resolvins in inflammation: Emergence of the pro-resolving superfamily of mediators. J. Clin. Investig. 2018, 128, 2657-2669. [CrossRef] [PubMed]

23. Paul, M.; Bruning, G.; Bergmann, J.; Jauch, J. A thin-layer chromatography method for the identification of three different olibanum resins (Boswellia serrata, Boswellia papyrifera and Boswellia carterii, respectively, Boswellia sacra). Phytochem. Anal. 2012, 23, 184-189. [CrossRef] [PubMed]

24. Buchele, B.; Simmet, T. Analysis of 12 different pentacyclic triterpenic acids from frankincense in human plasma by highperformance liquid chromatography and photodiode array detection. J. Chromatogr. B Analyt. Technol. Biomed. Life Sci. 2003, 795, 355-362. [CrossRef]

25. Frank, A.; Unger, M. Analysis of frankincense from various Boswellia species with inhibitory activity on human drug metabolising cytochrome P450 enzymes using liquid chromatography mass spectrometry after automated on-line extraction. J. Chromatogr. A 2006, 1112, 255-262. [CrossRef]

26. Lai, S.C.; You, R.I.; Chen, T.T.; Chang, Y.; Liu, C.Z.; Chen, H.P.; Wu, C. Rapid Identification of Commercial Frankincense Products by MALDI-TOF Mass Spectrometry. Comb. Chem. High. Throughput Screen. 2021. [CrossRef]

27. Sharma, N.; Bhardwaj, V.; Singh, S.; Ali, S.A.; Gupta, D.K.; Paul, S.; Satti, N.K.; Chandra, S.; Verma, M.K. Simultaneous quantification of triterpenoic acids by high performance liquid chromatography method in the extracts of gum resin of Boswellia serrata obtained by different extraction techniques. Chem. Cent. J. 2016, 10, 49. [CrossRef]

28. Safayhi, H.; Mack, T.; Sabieraj, J.; Anazodo, M.I.; Subramanian, L.R.; Ammon, H.P. Boswellic acids: Novel, specific, nonredox inhibitors of 5-lipoxygenase. J. Pharmacol Exp. Ther 1992, 261, 1143-1146.

29. Siemoneit, U.; Koeberle, A.; Rossi, A.; Dehm, F.; Verhoff, M.; Reckel, S.; Maier, T.J.; Jauch, J.; Northoff, H.; Bernhard, F.; et al. Inhibition of microsomal prostaglandin E2 synthase-1 as a molecular basis for the anti-inflammatory actions of boswellic acids from frankincense. Br. J. Pharmacol. 2011, 162, 147-162. [CrossRef]

30. Bergqvist, F.; Morgenstern, R.; Jakobsson, P.J. A review on mPGES-1 inhibitors: From preclinical studies to clinical applications. Prostaglandins Other Lipid Mediat. 2020, 147, 106383. [CrossRef]

31. Smith, W.L.; Urade, Y.; Jakobsson, P.J. Enzymes of the cyclooxygenase pathways of prostanoid biosynthesis. Chem. Rev. 2011, 111, 5821-5865. [CrossRef] 
32. Verhoff, M.; Seitz, S.; Paul, M.; Noha, S.M.; Jauch, J.; Schuster, D.; Werz, O. Tetra- and pentacyclic triterpene acids from the ancient anti-inflammatory remedy frankincense as inhibitors of microsomal prostaglandin E(2) synthase-1. J. Nat. Prod. 2014, 77, 1445-1451. [CrossRef]

33. Syrovets, T.; Gschwend, J.E.; Buchele, B.; Laumonnier, Y.; Zugmaier, W.; Genze, F.; Simmet, T. Inhibition of IkappaB kinase activity by acetyl-boswellic acids promotes apoptosis in androgen-independent PC-3 prostate cancer cells in vitro and in vivo. J. Biol. Chem. 2005, 280, 6170-6180. [CrossRef]

34. Catanzaro, D.; Rancan, S.; Orso, G.; Dall'Acqua, S.; Brun, P.; Giron, M.C.; Carrara, M.; Castagliuolo, I.; Ragazzi, E.; Caparrotta, L.; et al. Boswellia serrata Preserves Intestinal Epithelial Barrier from Oxidative and Inflammatory Damage. PLoS ONE 2015, 10, e0125375. [CrossRef] [PubMed]

35. Governa, P.; Marchi, M.; Cocetta, V.; De Leo, B.; Saunders, P.T.K.; Catanzaro, D.; Miraldi, E.; Montopoli, M.; Biagi, M. Effects of Boswellia Serrata Roxb. and Curcuma longa L. in an In Vitro Intestinal Inflammation Model Using Immune Cells and Caco-2. Pharmaceuticals 2018, 11, 126. [CrossRef] [PubMed]

36. Tabas, I.; Glass, C.K. Anti-inflammatory therapy in chronic disease: Challenges and opportunities. Science 2013, 339, 166-172. [CrossRef] [PubMed]

37. Hammarberg, T.; Radmark, O. 5-lipoxygenase binds calcium. Biochemistry 1999, 38, 4441-4447. [CrossRef]

38. Steinhilber, D.; Herrmann, T.; Roth, H.J. Separation of lipoxins and leukotrienes from human granulocytes by high-performance liquid chromatography with a Radial-Pak cartridge after extraction with an octadecyl reversed-phase column. J. Chromatogr. 1989, 493, 361-366. [CrossRef]

39. Pace, S.; Pergola, C.; Dehm, F.; Rossi, A.; Gerstmeier, J.; Troisi, F.; Pein, H.; Schaible, A.M.; Weinigel, C.; Rummler, S.; et al. Androgen-mediated sex bias impairs efficiency of leukotriene biosynthesis inhibitors in males. J. Clin. Investig 2017, 127, 3167-3176. [CrossRef]

40. Werner, M.; Jordan, P.M.; Romp, E.; Czapka, A.; Rao, Z.; Kretzer, C.; Koeberle, A.; Garscha, U.; Pace, S.; Claesson, H.E.; et al. Targeting biosynthetic networks of the proinflammatory and proresolving lipid metabolome. FASEB J. 2019, 33, 6140-6153. [CrossRef] 